Loading

The Journal of the Canadian Game Studies Association

\title{
Not Yet Game Over: A Reappraisal of Video Game Addiction
}

\section{Jiow Hee Jhee, Qin Ting Lye and Kenneth Woo}

Volume 12, Number 19, Winter-Spring 2019

URI: https://id.erudit.org/iderudit/1058317ar

DOI: https://doi.org/10.7202/1058317ar

See table of contents

Publisher(s)

Canadian Game Studies Association

ISSN

1923-2691 (digital)

Explore this journal

Cite this article

Jhee, J., Lye, Q. \& Woo, K. (2019). Not Yet Game Over: A Reappraisal of Video Game Addiction. Loading, 12(19). https://doi.org/10.7202/1058317ar

\section{Article abstract}

The rapid expansion of video gaming in an internet-using society has brought on a renewed focus on the phenomenon of video game addiction. Despite this focus, there remains a crucial absence of consensus over the diagnostic criteria of video game addiction. Currently both psychological and behavioral interventions regard screen time as an indicator of video game addiction. However, these interventions are challenged by substantial literature that increasingly regard time to not be a predictor of addiction. To build onto the work that has been done, this paper argues that time is an inadequate criterion in which to ascertain video game addiction, proposing that a physiological-based criteria be used in conjunction with contextualized understandings of video game dynamics to approach video game addiction. This realignment is all the more pressing as video games begin a transition from a leisure activity to its current orientation as a viable career option.
Copyright Jiow Hee Jhee, Qin Ting Lye, Kenneth Woo, 2019

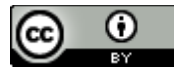

This document is protected by copyright law. Use of the services of Érudit (including reproduction) is subject to its terms and conditions, which can be viewed online.

https://apropos.erudit.org/en/users/policy-on-use/ 


\title{
Reappraisal of Video Game Addiction for the Digital Future
}

\author{
Jiow Hee Jhee \\ Singapore Institute of Technology \\ Jhee.Jiow@SingaporeTech.edu.sg \\ Lye Qin Ting \\ Singapore Institute of Technology \\ Janinelye@gmail.com \\ Kenneth Woo \\ Singapore Institute of Technology \\ Kenneth.Woo@SingaporeTech.edu.sg
}

\begin{abstract}
The rapid expansion of video gaming in an internet-using society has brought forth a renewed focus on the phenomenon of video game addiction. Despite this, there remains a crucial absence of consensus over the diagnostic criteria of video game addiction. Currently, both psychological and behavioral interventions take screen time as an indicator of video game addiction, however, these interventions are challenged by substantial literature that increasingly disputes time as a predictor of addiction. To build onto the work that has been done, this paper argues that time is an inadequate criterion in which to ascertain video game addiction, proposing that a physiological-based criteria be used in conjunction with contextualized understandings of video game dynamics to approach video game addiction. This realignment is all the more pressing as video games begin a transition from a leisure activity to its current orientation as a viable career option.
\end{abstract}

\section{Author Keywords}

Addiction; Video Games; Screen Time

\section{Introduction}

The phenomenon of video game addiction is one that plagues a segment of internet-using society. Through barometers assessing psychological inclinations, social life exposure, gaming habits and an assortment of other factors, many have been deemed to be suffering from this condition (Király, Nagygyörgy, Griffiths, \& Demetrovics, 2014; Shaffer et al., 2004). Problematically, however, whilst research and treatment efforts have been earnest and varied (see Byun et al., 2009; Ferguson, Coulson, \& Barnett, 2011; Griffiths, 2008b; Liu, 2014; Sepehr \& Head, 2013; Starcevic \& Aboujaoude, 2016; Young, Pistner, O'Mara, \& Buchanan, 1999), there remains an absence of consensus over diagnostic criteria of video game addiction 
(Hellman, Schoenmakers, Nordstrom, \& Van Holst, 2013; Király et al., 2014). The definitional lacuna notwithstanding, psychological and behavioral interventions have also consistently regarded screen time as an indicator of video game addiction (see Charlton, 2002; Chiu, Lee, \& Huang, 2004; Lin, Hsu, Wu, \& Chang, 2013; Simmons, 2008). Yet, such intervention tactics fly in the face of literature that are increasingly critical of time as a predictor of video game addiction (see Cummings \& Vandewater, 2007; Ferguson et al., 2011; Gentile, 2011; Groves et al., 2015). In tandem with these studies, this paper argues that the temporal is an inadequate criterion for ascertaining video game addiction. The stance rests on the manner of which video games have transitioned from its initial purpose of leisure to its current orientation as a viable career option (Jiow et al., 2018). Given how the use of video games has evolved, using screentime as a measure of video game addiction no longer holds any value, as it is now a form of livelihood for some, and not solely a past-time or form of entertainment.

Leveraging the shortcomings of time as a predictor of gaming addiction, this paper fuses the works of Groves et al. (2015), Smith (1997) and Király et al. (2014) to highlight the physical toll exerted by pathological gaming. Doing this not only compensates for the inadequacies of the temporal axis, but also provides an opportunity for other thought-worthy factors to be brought to the table. This ultimately leads to the paper's proposal for physiological-based criteria and contextualized understanding of game dynamics to be adopted when approaching video game addiction. Beginning with a brief exploration of the history of video game addiction, the paper addresses the evolution of video gaming and how this has impacted perspectives on the sector. It then proceeds to explore existing debates of video games and their pathological usage. The paper lastly concludes by reiterating that physiological complications resulting from compulsive gaming habits should also be considered when ascertaining if an individual suffers from video game addiction.

\section{History of Video Gaming Addiction}

The early 1970s witnessed video games in its infancy, when gaming machines and home-gaming consoles were first introduced (Kowert \& Quandt, 2016). From Pong and Space Invaders to sports games such as Table Tennis and Hockey, commercial video games laid the groundwork for the cultivation of the eventual multi-billion-dollar industry (Norman, 2017). According to Green and Kaufman (2015), the United States game industry raked in approximately \$20.77 billion in 2012, with over 50\% of Americans playing video games in 2013. As of 2017, the prevalence of video games has spread to $65 \%$ of American homes, with consumer spending standing at \$30.4 billion in 2016 (Entertainment Software Assocation, 2017). Such figures contrast sharply with those of the late 1990 s, when a mere $30 \%$ of Americans played video games (Balter, 2000).

It is unsurprising that video game addiction became a sequela of video game consumption (Kowert \& Quandt, 2016). When reports of 'Space Invasion obsession' and 'computer catatonia' surfaced in the early 1980s, the public concern it drew inadvertently paved a newfound path for scholarly research (Rössler, 2017). It was Soper and Miller, as cited in Rössler (2017) whose works first alluded to the term 'video game addiction'. Since then, the theoretical footpaths many academics have trodden upon are wide and varied. While early studies examined video games through a generic lens, those embarked on after the 2000s scrutinized the effects of: online and Massively Multiplayer Online Role-Playing Games (MMORPGs) (Granic, Lobel, \& Engels, 
2014; Király et al., 2014; Kowert \& Quandt, 2016); the detriments and benefits of video game playing (Ferguson, 2007; Lobel, Engels, Stone, Burk, \& Granic, 2017; Prot, Anderson, Gentile, Brown, \& Swing, 2014); and its relation to violence, aggression, and real life mass killing incidents (Birkland \& Lawrence, 2009; Ferguson, Bowman, \& Kowert, 2017; Markey, Markey, \& French, 2014).

There is also a need to acknowledge a portion of scholars who have put forth the position that 'video game addiction' is either a premature concept that has yet to earn its place as an official medical diagnosis (Bean, Nielsen, Van Rooij \& Ferguson, 2017) or an issue that does not yet render a need for it to be classified as a disorder without determining if it is just a subset or symptomatic of generic behavioral issues (Van Rooij et al., 2018). The thread of commonality that ties the perspectives of these authors together, nonetheless, rests on arguments that research conducted thus far remains insufficient, is not comprehensive, or it suffers from methodological flaws. Trailing shortly behind are also concerns over clinical implications (e.g. misdiagnosis and treatment), increased moral panic, and social stigma (Bean, Nielsen, Van Rooij \& Ferguson, 2017; Van Rooij et al., 2018).

It is not the intention of the paper to enter into the conceptual debate of video game addiction regardless of the vast amount of literature, the definition of 'video game addiction' remains in murky waters (Hellman et al., 2013; Király et al., 2014). Rather, it borrows Rosen, Cheever, and Carrier's (2015) position around how the general public's conception of video game addiction is a subsection of Internet Gaming Disorder (IGD). This framework is derived specifically from the pioneering work of Young et al. (1999). Of internet addiction subtypes, Computer Addiction was listed as one subdivision, characterized by an individual's excessive game playing (Young et al., 1999). The highly influential piece successively shaped many studies, regardless of roots in psychology (Bélanger-Lejars, 2015), academia or policy (Ferguson et al., 2011). The extent to which it remains relevant to contemporary times, therefore, is an aspect that this paper endeavors to verify.

\section{Problematizing Video Game “Addiction”}

Taking the cue from scholars such as Király et al. (2014) and Granic et al. (2014), the term 'video game' is used as an umbrella term to represent the myriad games, both online and offline, that can be played across devices (laptops, gaming consoles, mobile phones, etc.) with varying levels of player-engagement. As it is not the aim of this paper to partake in the discourse of terminology, this paper too shall use 'video game(s)' to represent different manifestations of the cyber-gaming playground.

'Addiction', contrastingly, is commonly comprehended in the psychological context (Hellman et al., 2013). In the works of Peele (1985), addiction revolves around the core elements of tolerance, withdrawal and craving, where over-dependence on a stimulus exacts substantial hardship on the individual upon discontinuation. A similar conceptualization was also used by Byun et al. (2009), where addiction is tied to socio-functional impairments resulting from an individual's overuse of a stimulus. Significant pieces of video game addiction literature feature its proposed inclusion into the 2013 Internet Gaming Disorder in the fifth edition of the Diagnostic and Statistical Manual of Mental Disorders (DSM-5) (American Psychiatric Association, 2018) and its recognition as an official disorder in the $11^{\text {th }}$ revision of the 
International Classification of Diseases (World Health Organization, 2018). It was a decision propelled by the multiple similarities shared between gaming disorders and gambling addiction (Bélanger-Lejars, 2015; Kuss \& Griffiths, 2012). A point of variance that distinguishes video gaming addiction from its gambling counterpart lies in how 'addiction' is often loosely used to denote excessive behaviors for the former, as opposed to the drug-like psychological struggle characteristic of the latter (Hellman et al., 2013). This contrast thus makes it imperative to be mindful that what is excessive is not the same as addiction, especially with 'addiction' carrying insinuations of mental health issues (Starcevic \& Aboujaoude, 2016). Hence, the need for a clear delineation and conceptualization of the 'addiction' terminology discharges a primary obligation for academics and medical professionals alike to recalibrate current understandings of "video game addiction'.

\section{Video Games and Violence}

Violence is undoubtedly one of the central tenets in the discourse of video game addiction (Anderson, 2016; Ferguson, 2007; Markey et al., 2014). Specifically, violent video games came under intense academic and public scrutiny in the chaos ensuing from the Columbine School shooting (Birkland \& Lawrence, 2009). Some believe that continuous play of violent video games contributes to the accumulation of violence and aggression within players (Brunborg, Mentzoni, \& Frøyland, 2014), thus resulting in a transference of violent characteristics from the cyber terrain to the physical one (Anderson, 2016). Fanning the sparks of concern were several other incidences that the news media have repeatedly linked video games to. Several other landmark school shootings and incidences include the April 1999 Columbine shooting (Birkland \& Lawrence, 2009), the 2007 Virginia Tech University shooting (Markey et al., 2014), followed by the killings perpetrated by Anders Breivik in Norway in 2011 (Meloy, Habermeyer, \& Guldimann, 2015) as well as the December 2012 Sandy Hook Elementary School shooting in Newtown, Connecticut (Fox \& DeLateur, 2013).

With violence portrayed as a significant harm of video games, a whole host of other issues were gradually presented as being equally worrisome. These include emotional desensitization (Carnegey, Anderson, \& Bushman, 2007), diminished prosocial and empathetic behavior, mood disorders such as depression and anxiety (Brunborg et al., 2014; Lobel et al., 2017), impeded decision-making abilities with hostility as a default response mechanism (Prot et al., 2014) and reduced attention span and self-control (Lobel et al., 2017; Prot et al., 2014). Still, causality between violent video games and violent behavior is debatable (Brunborg et al., 2014; Lobel et al., 2017).

As Kowert and Quandt (2016) critically reminds, it is inherently problematic to assume that video gamers are passive recipients of video gaming content when in fact, behavioral development is a multifactorial process. At this juncture, it is also imperative to inject that not all video games are violent (Gentile, 2003). Though common-sensical, this is a point that is frequently banished to the background whenever discussions on violence in video games take place. Games subsumed under the non-violent genre include Candy Crush, Farmville, Tetris, Super Mario and sports-themed games such as Wii Sports. Purposes of leisure aside, video games have also been roped into education in the form of Edutainment (Egenfeldt-Nielsen, Smith, \& Tosca, 2016) and even as a modern alternative to conventional sports via Exergames (Peng, Lin, \& Crouse, 2011). In acknowledging that non-violent video games also exist, it 
reinforces the notion that those who fall prey to video game addiction may hail from any genre of game whereby violence is not a prerequisite (Bostan, 2016). More importantly, such perspectives equalize the scale of detriments by reflecting that players too, can be recipients of benefits brought by video games.

\section{Benefits of Video Games}

With the proliferation of the video game industry, studies and observations have, and are still, providing evidence of the benefits of video gaming. Prensky (2006), for example, writes that video games aid players in learning essential life skills through play, such as improving upon their hand-eye coordination and prioritizing abilities during exposure to multiple stimulants (similar to the cyber playground, Peterson (2013)). Prensky also advanced that video games help with elements of socialization, cognitive development and skills, as well as spatial visualization abilities. Kowert and Quandt (2016) observed that video games foster stronger social bonds between family and peers, therein supporting overall emotional contentment.

Aside from personal advantages, other studies also addressed the inclusion of video games into the education sector (Gentile, 2011). According to Suziedelyte, apart from piquing students' interest in learning, games were found to develop better problem-solving skills (cited in De Queirós \& Pinto, 2017). Relatedly, video games are being used in the medical field, where simulation games help train medical practitioners on a level that mimics real-life scenarios (De Freitas, Ott, Popescu, \& Stanescu, 2013; Granic et al., 2014; Rosser et al., 2007). Similarly, video games are also being integrated into trainings for military and governmental personnel (Susi, Johannesson, \& Backlund, 2007). Hence, the adjacent argument of the video game debate presents the pros of video gaming in terms of cognitive, motivational, emotional and (pro) social developments in which gamers and non-gamers alike stand to gain.

\section{Approaching through Dysfunctions}

Information gleaned from texts suggest that video game addiction is commonly delineated via impairments to daily life functions (Ferguson et al., 2011; King, Delfabbro, Griffiths, \& Gradisar, 2011). Well-known consequences of pathological gaming include deteriorated physical health, worsened emotional wellbeing, limited social life and academic/career non-performance are (Griffiths \& Meredith, 2009; Groves et al., 2015; King et al., 2011; Kuss \& Griffiths, 2012; Petry et al., 2014). Wolf (2012) spotlights specifically that psychologists frequently use the duration of play, quality of sleep, professional or academic (non)performance, as well as (the lack of) social life as markers of video game addiction. Due to the compulsion to engage in video games, players often sacrifice sleep, thus neglecting their physical health and destabilizing patterns of work-life balance. When attention is excessively invested into video games, the gaming arena becomes so central to the individual that other aspects such as social life and academic performance take a nosedive (Groves et al., 2015; Kuss \& Griffiths, 2012; Liu, 2014; Petry et al., 2014; Sussman, 2017).

As Anderson, Gentile, and Buckley (2007) find, there is a sturdy chain that links screen time to poorer academic performance. Gentile et al. (as cited in Jordan \& Romer, 2014) describe this as the displacement hypothesis, where time that was originally meant for study is now used for 
gaming instead. Subsequently, as pathological gaming habits and a preoccupation with games begin to take root, overall academic performance declines while problematic conduct climbs. This may surface through shortened attention span, reduced impulse control, truancy (Kowert \& Quandt, 2016), skipping homework in favor of playing video games (Gentile et al., 2009 as cited in Jordan \& Romer, 2014) and poorer reading and writing capabilities (Weis \& Cerankosky, 2010). Gradually, the importance of scholastic achievements becomes displaced by gaming conquests.

Similarly, pathological gaming has been argued to have a diminishing effect on physical social life (Liu, 2014; Sussman, 2017). McEwan (2015) calls this phenomenon cocooning - where online social interaction displaces physical interaction, a phenomenon especially prevalent among individuals that struggle with offline relationships. For Oliver and Raney (2014), immersive video games have the propensity to immerse gamers so fully in the cyberworld that physical social life ceases to be important. In this sense, there is a breakdown of social interaction and communication with peers and family in favor of online social interaction. As pathological gamers distance themselves from physical interaction, more severe implications arise, as opportunities for the development of social skills, knowledge of behavioral norms, and communication methods dwindle to the point that real-time communication becomes a hurdle (Kowert, 2015). Therefore, the ripple effect of consequences blossoming from excessive video game consumption is what fuels many worries and condemnation of video games amongst parents.

\section{Social Life through Computer Mediated Communications (CMC)}

The prior section underscored that physical social life is vulnerable to the negative effects of pathological gaming. This is because in the current technologically-advanced era, online communication is a norm for many societies (Arnett, 2007). Channels such as email and instant text messaging are used to supplement traditional forms of communication, and it is precisely due to this supplementary effect that many view online mediated communication as beneficial to social life. In the aspect of video games, Steinkuehler and Williams (2006) found that gaming chat rooms could either be private and restricted to selected players, or open to the public. The content of the chat rooms featured everything from information on completing the games, to strategizing, or even personal opinions on politics and art (Steinkuehler \& Williams, 2006).

In this vein, video games do encourage social interaction in its own way, as gaming chat rooms not only facilitate informational exchange, but also boost social capital to stitch the virtual to the real world and vice versa. Bringing it a step further, Cole and Griffiths (2007) found that nearly $43 \%$ of online friends meet in real-life, while EmBrick, Wright, and Lukacs (2012) reported that video games were used as a common channel by undergraduates to bond with each other. The strength of video games as a channel for establishing social capital could also be seen in the work of Goldstein et al. in 1997 (as cited in Kunstler \& Daly, 2010) and Silton (2014), where elders in nursing homes and children with Autism Spectrum Disorder, respectively, all managed to engage in communication through video games.

A particularly interesting point worthy of exploration is what Cole and Griffiths (2007) cite as the disinhibition effect, which explores how some gamers find security in the anonymity of gaming to help strengthen their cyber social lives. For these individuals, they feel at ease when 
communicating with others in the online sphere, and this cyber contact compensates for their lack of offline relationships (McEwan, 2015). Against this backdrop, therefore, it is not difficult to comprehend why Király et al. (2014) argue that video gaming and social life are not mutually exclusive. Instead, it would be negligent to simply restrain understandings of 'social life' to conventional ideas revolving around the physical because cyber social life possesses an influence strong enough for it to transcend into the physical world.

\section{Measurement Apparatuses of Video Game Addiction}

One of the most widely-used scales for the evaluation of video game addiction is the Nine-item short-form Internet Gaming Disorder Scale (thereafter IGDS-SF9) (Pontes \& Griffiths, 2015). This psychometric assessment tool imposes the condition that an individual must fulfil a minimum of five of the nine criteria, in addition to having his or her life being significantly hindered by their gaming patterns (Pontes, Király, Demetrovics, \& Griffiths, 2014). The nine criteria listed are: (1) Preoccupation - a fixation with online games; (2) Tolerance - gradual increase in playing duration to attain existing personal gratification; (3) Withdrawal - the onset of frustration and negative emotions as a result of non-play; (4) Persistence - the inability to consciously keep oneself away from video games; (5) Escape - the adjustment to alternative forms of mental states or conduct to east the distress inflicted by withdrawal symptoms; (6) Problems - the obsessive continuance with gameplay despite knowledge of ramifications; (7) Deception - keeping one's thirst for gaming a secret from others; (8) Displacement deterioration of daily routine and lifestyle by gaming; (9) Conflict - the stage when gaming has become significantly detrimental to one's social relationships, personal life, career opportunities and various other aspects (Lemmens, Valkenburg, \& Gentile, 2015; Pontes et al., 2014).

Comparably, there are also other methodologies, including the Game Addiction Scale proposed by Lemmens, Valkenburg, and Peter (2009) and the Problematic Online Game Use (POGU) scale introduced by Haagsma, Caplan, Peters, and Pieters (2013). Considering that each study has its set of strengths and weaknesses, it was found that conceptualizations of each study's measurements and indicators differ from the others. Király, Griffiths, and Demetrovics (2015), for instance, critiqued the IGDS-SF9 scale, suggesting it was unsuitable for its purpose because its theoretical infrastructure was created by superimposing the diagnostic framework of gambling and substance abuse, based on a study from China. In doing so, the authors argue, it inherently assumes that addictions are comparable while disregarding unique contextual factors (Király et al., 2015). Findings from Stavropoulos et al. (2017) reflected that in different countries and cultural contexts, levels of 'addiction' severity differed even when same scores were obtained. For the POGU scale, M. G. Kim and Kim (2010) identified from their overview a key shortcoming that found the POGU incapable of being administered in different cultural contexts or to adults with gaming pathologies.

\section{The Inaccuracy of Using Time as a Measure}

From its onset, gaming addiction has been synonymous with the idea of excessive gaming duration. The use of time as an indicator of video game addiction can be found in many texts (Charlton, 2002; Chiu et al., 2004; Griffiths, 2008a; Király et al., 2015; Lin et al., 2013; Simmons, 2008), to the extent that time has become a common factor running across the abovementioned studies. While there is a certain truth to the idea that game addicts engage in 
large amounts of screen time (Király et al., 2014, 2015), it certainly does not render valid the use of time as a factor to pinpoint video game addiction.

The tunnel vision of using time as a measure, as Gentile (2009) argues, is inaccurate and unsuitable an apparatus for measuring and diagnosing video gaming addiction. The fundamental argument made was simply - 'The amount of time spent playing is not a criterion for pathological video-game use, just as how much one drinks is not criterion for alcohol dependence' (p. 600). This means that video gamers cannot be unquestionably diagnosed as a 'video game addict' based simply on the duration of gameplay because if so, then all players that have hit that particular temporal threshold would be classified as 'video game addicts'. Where those with a profession in video games are concerned, then, it would be unreasonable to label them as 'game addicts' considering that their consumption of video games are within the scope of their job. By specifically extracting the duration of gameplay, its weightage in directing conceptions of game addiction destabilizes the objectivity of many measurement tools, thereby compounding the risk of obtaining invalid results and over-diagnosis (Ferguson et al., 2011; Petry et al., 2014).

On a separate line of argument, there is also a need to account for media multitasking - the way in which an individual is concurrently occupied with two or more forms of media (Foehr, 2006). It is a common occurrence in everyday life, as exemplified by people listening to music while surfing the internet, or watching videos while chatting online. In video games such as Starcraft, gamers strategize their battles while deploying avatars to acquire more resources (Granic et al., 2014), all the while being engaged in chat rooms or listening to their favorite songs. Media multitasking has been found to equip gamers with better strategizing abilities, hand-eye coordination, negotiation, adaptability, reactiveness, working memory and overall cognition (Baniqued et al., 2014; Murphy, 2009; Susi et al., 2007).

While there are studies arguing that video games do not allow for multitasking due to the amount of concentration required (Anguera \& Gazzaley, 2015; Cotton, Shank, \& Anderson, 2014), this paper contends that the ability to multitask is contingent on the type of game and how immersive it is. This standpoint parallels that of Granic et al. (2014), whom posited that the more casual the game, the easier it is to multitask. Unlike real-time strategy games, casual games are less intense and mentally engaging, thus tuning down the amount of focus needed. The Sims, Halo, FIFA, Farmville, Candy Crush and Hay Day are some examples of games that provide an affordance for media multitasking (Knautz \& Baran, 2016).

\section{An Impetus for Changing Current Perspectives: Transitions in Perspectives of VG Careers}

As one of the forces propelling renewed perspectives on video games, new careers related to video gaming surfaced following the proliferation of the video gaming sector. Though specialists in the field of programming, design, animation, acoustics, illustration, scripts and graphics are quintessential in the production of video games (Cohendet \& Simon, 2007; Crosby, 2000; Ruggill, McAllister, Nichols, \& Kaufamn, 2017), it was those professions that raked in an income via video gaming that caught the most attention; the very same careers that were previously perceived as unconventional and non-practical (Jiow et al., 2018). 
Being a professional gamer (thereafter pro-gamer), for one, is a career aspiration for many video gamers (Li, 2016; Taylor, 2012). Pro-gamers participate in competitive video game tournaments of which spectatorship is an integral component (Hollist, 2015). Fame and success in the progaming scene is reserved for those who can conquer the onerous competition and power through its short-lived glory (Jin, 2010). Yet, once a pro-gamer's reputation has been solidified, earnings from tournament winnings, branding, advertising, ambassadorship, and streaming activities are integral in sustaining the career (Hamilton et al., 2012, as cited in Edge, 2013). This is especially true for gamers in countries such as South Korea, Japan, China, the United States and certain parts of Europe where video games have earned recognition as a legitimate 'sport' in its own right (Edge, 2013; Hollist, 2015; Jin, 2010; Tan, 2017).

In these countries, pro-gamers train hard for the sole aim of winning international gaming competitions such as the World Cyber Games competition (S. H. Kim \& Thomas, 2015) and the Cyberathlete Professional League (Mora \& Héas, 2003). As S. H. Kim and Thomas (2015), gather, 2015 alone saw pro-gaming as a US\$0.26 billion market. Singapore has begun to set its sights on the burgeoning e-Sports market, playing host to the Vainglory World Championship, a mobile game competition with a prize pool of $\$ 191,000$ (Hio, 2017b). Winners of such tournaments were also observed to enjoy celebrity status and improved social seating within their respective cultures (Edge, 2013; Jin, 2010; Li, 2016; Taylor, 2012). This is the case for South Korean pro-gamer, Yo-Hwan Lim, who at one point had 650,000 fans (Jin, 2010), which not only vouches for his popularity, but also the social benefits brought by this vocation. In Singapore, several local players have also enjoyed increased earnings and benefits from participating in such tournaments, such as Amos Ker, who estimated that he has earned $\$ 7,000$ from Vainglory competitions (Hio, 2017c). Local gaming teams like Chaos Theory have also set up a pro-gaming team that enjoys full employment benefits such as regular paychecks and medical benefits (Hio, 2017a, 2017d). Organizations such as the Singapore Cybersports \& Online Gaming Association (SCOGA) have conducted classes on e-sports and livestreaming, enjoying healthy enrolment in these classes since its inception (Hio, 2017d). As such, it is plain to see why the pro-gaming scene holds such great allure.

In a Singapore-based study conducted by Jiow et al. (2018), it was discovered that vocations as a game-designer were more readily accepted by parents and children than those as a YouTuber or pro-gamer. Even as a job that is more active behind-the-scenes, game designers form a key pillar in the entire creation process of video games (Liming \& Vilorio, 2011). Such sentiments arose from the perspective that skills in game-design were considerably more transferable and less restricted to the sole mechanics of game playing (Jiow et al., 2018). The same was echoed by Lee and Lin (2011), Liming and Vilorio (2011), and Weststar (2015).

Even for supposedly 'addicted' gamers, there is still hope for them in finding a job outside of the video gaming archipelago. Working on the same theme of 'transferable skills', SCOGA (2017) and Kingmaker Consultancy (2017) both adopt a strength-based approach to engaging 'addicted gamers'. In this sense, specific skills that clients exhibit during gaming are specially honed so that the same skills can be applied in a (non-video-gaming) workplace setting. In sum, all these works help reshape the contours of what positions in the video game industry entail, and how past perspectives are slowly but surely being replaced by fresh ideas. 


\section{The Physiological \& Contextualized Approach}

Shaffer et al. (2004) offer a compelling argument for the cruciality of revising conceptualizations of 'addiction' by spotlighting how readily the public diagnoses of certain conducts as 'addictions' via a narrow focus on risk factors and deviant behaviors. The salience of calling for such a revision has implications not only for future research efforts, but treatment pathways as well (see Byun et al., 2009; Griffiths \& Meredith, 2009; Groves et al., 2015; King et al., 2011). It reasons to say that pathological video gaming, like most other activities, imposes physiological tolls when done excessively (Griffiths, Kuss, \& King, 2012). Yet, physical complications resulting from frequent, compulsive gameplay seem to be often disregarded in the assessment of video game addiction. By categorizing a segment of video game addiction theories to the physiological, this paper follows the position taken by Groves et al. (2015), where 'video game addiction' should also be determined based on the infliction of clinically significant impairment(s) to one's daily lifestyle.

Physiological issues arising from addictive gameplay do not veer far from Smith's (1997) insight into Computer Related Syndrome. It includes disruptions to sleep, appetite, hygiene (Király et al., 2014) to optical issues such as deteriorating vision, eye dryness, and fatigue (Smith, 1997), to more severe conditions like carpal tunnel syndrome, migraines (Griffiths, 2008a) and spinal issues resulting from poor posture and prolonged sitting (Hiltscher \& Scholz, 2017).

Where physiological conditions are related, the type and dynamics of the games played would also be an essential factor to consider - contextualized approach. Essentially, as Gentile (2011) suggests, video games and the phenomenon of addiction must be considered in a wholesome and contextualized manner. Simply put, the individual addicted to playing computer or Virtual Reality video games would very likely suffer from a differing degree of health issues as compared to those who are compulsively playing mobile or console-based games (Hiltscher \& Scholz, 2017; Ramos, James, \& Bear-Lehman, 2005). In light of all these factors, the physiological issues stemming from compulsive video gaming should be given more, if not equal, consideration as those of its functional counterpart. This notion is made even more pressing particularly because the treatment of such medical conditions are more often than not relegated to the sidelines of video game addiction treatments.

\section{Conclusion}

To conclude, this paper has sought to address two key issues. Firstly, the use of time as an indicator of video game addiction was considered against the backdrop of developments in media-usage. As a result of media multitasking (Foehr, 2006), computer mediated communication (Arnett, 2007) and a growing acceptance and uptake of careers in video gaming (Jiow et al., 2018), the ways in which time used to be allocated solely for video games are now stretched to include a variety of other activities and purposes. Consequently, this means that previous method(s) designed for measuring 'time spent on playing video games' can no longer be applied to contemporary contexts without incurring significant risk of over-diagnosis (Ferguson et al., 2011; Petry et al., 2014). The second issue focused on the proposition that physiological conditions should be taken into account in future assessments of "video game addiction'. Putting aside concerns over dysfunctions in daily routines inflicted by pathological 
gaming patterns, this writing has additionally asserted that physiological harm should also be incorporated in future assessments of video game addiction. Physiological harms would be a replacement of the temporal indicator as it is a factor more fitting and easily-assessed to deduce if one's gaming tendencies have reached a scale where it is a detriment to the self. Stitching these two themes together, the paper hopes that better assessment tools meant for diagnosing video game addictions can be formulated to suit the contextualized and ever-changing trends of the video-game dimension.

\section{References}

American Psychiatric Association (2018). Internet gaming. Retrieved from: https://www.psychiatry.org/patients-families/internet-gaming

Anderson, C. A. (2016). Media violence effects on children, adolescents and young adults. Health Progress, 97(4), 59-62.

Anderson, C. A., Gentile, D. A., \& Buckley, K. E. (2007). Violent video game effects on children and adolescents: Theory, research, and public policy. New York, NY: Oxford University Press.

Anguera, J. A., \& Gazzaley, A. (2015). Video games, cognitive exercises and the enhancements of cognitive abilities. Current Opinion in Behavioral Sciences, 4, 160-165.

Arnett, J. J. (Ed.) (2007). Encyclopedia of children, adolescents and the media. California: SAGE Publications.

Author, Author, Author, Author, Author, Author, \& Author. (2017). Perceptions of video gaming careers and its implications on parental mediation. Paper presented at the Popular Culture Association/American Culture Association 2017 Annual Conference, San Diego, CA.

Balter, L. (Ed.) (2000). Parenthood in America: An encyclopedia (Vol. 1-2). California: ABCCLIO.

Baniqued, P. L., Kranz, M. B., Voss, M. W., Lee, H., Cosman, J. D., Severson, J., \& Kramer, A. F. (2014). Cognitive training with casual video games: Points to consider. Frontiers in Psychology, 4, 1-19.

Bean, A.M., Nielsen, R.K.L., van Rooij, A.J., \& Ferguson, C.J. (2017). Video game addiction: The push to pathologize video games. Professional Psychology: Research and Practice, $1-12$.

Bélanger-Lejars, V. O. (2015). Internet gaming disorder and gambling disorder: A comparison of individual psychological factors. Journal of Psychology and Behavioural Science, 3(2), 122-140.

Birkland, T. A., \& Lawrence, R. G. (2009). Media framing and policy change after Columbine. American Behavioral Scientist, 52(10), 1405-1425.

Bostan, B. (Ed.) (2016). Gamer psychology and behavior. Switzerland: Springer Publishing. 
Brunborg, G. S., Mentzoni, R. A., \& Frøyland, L. R. (2014). Is video gaming or video game addiction, associated with depression, academic achievement, heavy episodic drinking or conduct problems? Journal of Behavioral Addictions, 3(1), 27-32.

Byun, S., Ruffini, C., Mills, J. E., Douglas, A. C., Niang, M., Stepchenkova, S., . . Blanton, M. (2009). Internet addiction: Metasynthesis of 1996-2006 quantitative research. CyberPsychology \& Behaviour, 12(2), 203-207.

Carnegey, N. L., Anderson, C. A., \& Bushman, B. J. (2007). The effects of video game violence on physiological desensitization to real-life violence. Journal of Experimental Social Psychology, 43, 489-496.

Charlton, J. P. (2002). A factor-analysis investigation of computer "addiction" and engagement. British Journal of Psychology, 93(Part 3), 329-344.

Chiu, S. I., Lee, J. Z., \& Huang, D. H. (2004). Video game addiction in children and teenagers in Taiwan. CyberPsychology \& Behaviour, 7(5), 571-581.

Cohendet, P., \& Simon, L. (2007). Playing across the playground: Paradoxes of knowledge creation in the videogame firm. Journal of Organizational Behavior, 28(5), 587-605.

Cole, H., \& Griffiths, M. D. (2007). Social interaction in massively multiplayer online role playing gamers. CyberPsychology \& Behaviour, 10(4), 575-583.

Cotton, S. R., Shank, D. B., \& Anderson, W. A. (2014). Gender, technology use and ownership, and media-based multitasking among middle school students. Computers in Human Behavior, 35, 99-106.

Crosby, O. (2000). Working so others can play: Jobs in video game development. Retrieved from https://www.bls.gov/careeroutlook/2000/Summer/art01.pdf

Cummings, H. M., \& Vandewater, E. A. (2007). Realtion of adolescent video game play to time spent in other activities. Archives of Pediatrics \& Adolescent Medicine, 161(7), 684-689.

De Freitas, S., Ott, M., Popescu, M. M., \& Stanescu, I. (2013). New pedagogical approaches in game enhanced learning: Curriculum integration. United States: Information Science Reference, IGI Global.

De Queirós, R. A. P., \& Pinto, M. T. (2017). Gamification-based e-learning strategies for computer programming education. United States: IGI Global.

Edge, N. (2013). Evolution of the gaming experience: Live video streaming and the emergence of a new web community. Elon Journal of Undergraduate Research in Communications, $4(2), 1-2$.

Egenfeldt-Nielsen, S., Smith, J. H., \& Tosca, S. P. (2016). Understanding video games: The essential introduction (3rd ed.). New York: Routledge.

EmBrick, D. G., Wright, J. T., \& Lukacs, A. (Eds.). (2012). Social exclusion, power, and video game play: New research in digital media and technology. United Kingdom: Lexington Books.

Entertainment Software Assocation. (2017). 2017 essential facts about the computer and video game industry. Retrieved from http://www.theesa.com/article/2017-essential-factscomputer-video-game-industry/

Ferguson, C., Coulson, M., \& Barnett, J. (2011). A meta-analysis of pathological gaming prevalence and comorbidity with mental health, academic and social problems. Journal Of Psychiatric Research, 45(12), 1573-1578.

Ferguson, C. J. (2007). The good, the bad and the ugly: A meta-analytic review of positive and negative effects of violent video games. Psychiatric Quarterly, 78(4), 309-316. 
Ferguson, C. J., Bowman, N. D., \& Kowert, R. (2017). Is the link between games and aggression more about the player, less about the game? In P. Sturmey (Ed.), The wiley handbook of violence and aggression (pp. 1-13). Hoboken, NJ: John Wiley \& Sons.

Foehr, U. G. (2006). Media multitasking among American youth: Prevalence, predictors and pairings. Henry J. Kaiser Family Foundation.

Fox, J. A., \& DeLateur, M. J. (2013). Mass shootings in America: Moving beyond Newtown. Homicide Studies, 18(1), 125-145.

Gentile, D. A. (2009). Pathological video-game use among youth ages 8 to 18: A national study. Psychological Science, 20(5), 594-602.

Gentile, D. A. (2011). The multiple dimensions of video game effects. Child Development Perspectives, 5(2), 75-81.

Gentile, D. A. (Ed.) (2003). Media violence and children: A complete guide for parents and professionals. London, UK: Praeger.

Granic, I., Lobel, A., \& Engels, R. C. M. E. (2014). The benefits of playing video games. American Psychologist, 69(1), 66-78.

Green, G. P., \& Kaufman, J. C. (Eds.). (2015). Video games and creativity. London, UK: Elsevier.

Griffiths, M. D. (2008a). Diagnosis and management of video game addiction. Directions in Addiction Treatment \& Prevention, 12(3), 27-42.

Griffiths, M. D. (2008b). Internet and video-game addiction. In C. A. Essau (Ed.), Adolescent addiction: Epidemiology, assessment, and treatment (pp. 231-268). London: Elsevier.

Griffiths, M. D., Kuss, D. J., \& King, D. L. (2012). Video game addiction: Past, present and future. Current Psychiatry Reviews, 8(4), 1-11.

Griffiths, M. D., \& Meredith, A. (2009). Videogame addiction and its treatment. Journal of Contemporary Psychotherapy, 39(4), 247-253.

Groves, C. L., Blanco-Herrara, J. A., Prot, S., Berch, O. N., McCowen, S., \& Gentile, D. A. (2015). What is known about video game and internet addiction after DSM-5. In L. D. Rosen, N. A. Cheever, \& L. M. Carrier (Eds.), The wiley handbook of psychology, technology and society (pp. 502-512). United Kingdom: Wiley Blackwell.

Haagsma, M. C., Caplan, S. E., Peters, O., \& Pieters, M. E. (2013). A cognitive-behavioral model of problematic online gaming in adolescents aged 12-22 years. Computers in Human Behavior, 29(1), 202-209.

Hellman, M., Schoenmakers, T. M., Nordstrom, B. R., \& Van Holst, R. J. (2013). Is there such a thing as online video game addiction? A cross-disciplinary review. Addiction Research \& Theory, 21(2), 102-112.

Hiltscher, J., \& Scholz, T. M. (Eds.). (2017). eSports yearbook 2015/16. Germany: BoD - Books on Demand.

Hio, L. (2017a, September 27). For former marine engineer, it's a dream come true. The Straits Times. Retrieved from http:/www.straitstimes.com/tech/games-apps/for-former-marineengineer-its-a-dream-come-true?xtor $=\mathrm{CS} 3-20$

Hio, L. (2017b, September 29). Mobile-game finalists to battle for \$191k in S'pore. The Straits Times. Retrieved from http://www.straitstimes.com/singapore/mobile-game-finalists-tobattle-for-191k-in-spore?xtor=CS3-20

Hio, L. (2017c, September 27). Teenager goes for games designed for mobile devices. The Straits Times. Retrieved from http://www.straitstimes.com/tech/games-apps/teenagergoes-for-games-designed-for-mobile-devices?xtor=CS3-20 
Hio, L. (2017d, September 27). Turning video gaming into a career choice. The Straits Times. Retrieved from http://www.straitstimes.com/tech/games-apps/turning-video-gaming-intoa-career-choice? $x$ tor $=\mathrm{CS} 3-20$

Hollist, K. (2015). Time to be grown-ups about video gaming: The rising eSports industry and the need for regulation. Arizona Law Review, 57, 823-847.

Jin, D. Y. (2010). Korea's online gaming empire. London, UK: MIT Press.

Jiow, H.J., Athwal, R.J.S., Chew, L.L., Elias, M.H., Lim, N., Lye, Q.T., Ng, X.Y., \& Woo, K. (2018). Perceptions of video gaming careers and its implications on parental mediation. First Monday, 23(2).

Jordan, A. B., \& Romer, D. (Eds.). (2014). Media and the well-being of children and adolescents. New York, NY: Oxford University Press.

Kim, M. G., \& Kim, J. (2010). Cross-validation of reliability, convergent and discriminant validity for the problematic online game use scale. Computers in Human Behavior, 26(3), 389-398.

Kim, S. H., \& Thomas, M. K. (2015). A stage theory model of professional video game players in South Korea: The socio-cultural dimensions of the development of expertise. Asian Journal of Information Technology, 14(5), 176-186.

King, D. L., Delfabbro, P. H., Griffiths, M. D., \& Gradisar, M. (2011). Assessing clinical trials of internet addiction treatment: A systematic review and CONSORT evaluation. Clinical Psychology Review, 31(7), 1110-1116.

Kingmaker Consultancy. (2017). Strengths-based cyber wellness coaching. Retrieved from https://www.kingmaker.com.sg/portfolio-view/strengths-based-cyber-wellness-coaching/

Király, O., Griffiths, M. D., \& Demetrovics, Z. (2015). Internet gaming disorders and the DSM5: Conceptualization, debates and controversies. Current Addiction Reports, 2(3), 254262.

Király, O., Nagygyörgy, K., Griffiths, M. D., \& Demetrovics, Z. (2014). Problematic online gaming. In K. P. Rosenberg \& L. C. Feder (Eds.), Behavioral addictions: Criteria, evidence, and treatment (pp. 61-95). London: Elsevier.

Knautz, K., \& Baran, K. S. (Eds.). (2016). Facets of Facebook: Use and users. Germany: De Gruyter.

Kowert, R. (2015). Video games and social competence. New York, US: Routledge.

Kowert, R., \& Quandt, T. (Eds.). (2016). The video game debate: Unravelling the physical, social, and psychological effects of digital games. Oxon: Routledge.

Kunstler, R., \& Daly, F. S. (2010). Therapeutic recreation leadership and programming. United States: Human Kinetics.

Kuss, D. J., \& Griffiths, M. D. (2012). Internet gaming addiction: A systematic review of empirical research. International Journal of Mental Health Addiction, 10(2), 278-296.

Lee, Y. H., \& Lin, H. (2011). 'Gaming is my work': Identity work in internet hobbyist game workers. Work, Employment and Society, 25(3), 451-467.

Lemmens, J. S., Valkenburg, P. M., \& Gentile, D. A. (2015). The internet gaming disorder scale. Psychological Assessment, 27(2), 567-582.

Lemmens, J. S., Valkenburg, P. M., \& Peter, J. (2009). Development and validation of a game addiction scale for adolescents. Media Psychology, 12(1), 77-95.

Li, R. (2016). Good luck have fun: The rise of eSports. New York: Skyhorse Publishing.

Liming, D., \& Vilorio, D. (2011). Work for play: Careers in video game development.

Occupational Outlook Quarterly, 55(3), 2-11. 
Lin, F. L., Hsu, T. Y., Wu, T. S., \& Chang, C. L. (2013). The effects of user involvement in online games, game-playing time and display duration on working memory. In D. Harris (Ed.), Engineering psychology and cognitive ergonmoics: Understanding human cognition (pp. 58-67). London: Springer.

Liu, C. (2014). Long term effects of video and computer game heavy use on health, mental health and education outcomes among adolescents in the U.S. (Ph.D. Dissertation), University of Illinois at Urbana-Champaign.

Lobel, A., Engels, R. C. M. E., Stone, L. L., Burk, W. J., \& Granic, I. (2017). Video gaming and children's pyschosocial wellbeing: A longitudinal study. Journal of Youth and Adolescence, 46(4), 884-897.

Markey, P. M., Markey, C. N., \& French, J. E. (2014). Violent video games and real-world violence: Rhetoric versus data. Psychology of Popular Media Culture, 4(4), 277-295.

McEwan, B. (2015). Navigating new media networks: Understanding and managing communication challenges in a net-worked society. London: Lexington Books.

Meloy, J. R., Habermeyer, E., \& Guldimann, A. (2015). The warning behaviours of Anders Breivik. Journal of Threat Assessment and Management, 2(3-4), 164-175.

Mora, P., \& Héas, S. (2003). From video gamer to e-Sportsman: Towards a growing professionalism of world-class players. La Pratique du Jeu Vidéo: Réalité ou Virtualité.

Murphy, S. (2009). Video games, competition and exercise: A new opportunity for sports psychologists. The Sport Psychologist, 23(4), 487-503.

Norman, K. L. (2017). Cyberpsychology: An introduction to human-computer interaction (2nd ed.). United Kingdom: Cambridge University Press.

Oliver, M. B., \& Raney, A. A. (Eds.). (2014). Media and social life. New York, NY: Routledge.

Peele, S. (1985). The meaning of addiction: Compulsive experience and its interpretations. Lexington: Lexington Books.

Peng, W., Lin, J. H., \& Crouse, J. (2011). Is playing exergames really exercising? A metaanalysis of energy expenditure in active video games. CyberPsychology, Behaviour and Social Networking, 14(11), 681-688.

Peterson, M. (2013). Computer games and language learning. New York, NY: Palgrave Macmillan.

Petry, N. M., Rehbein, F., Gentile, D. A., Lemmens, J. S., Rumpf, H. J., Mößle, T., . . O'Brien, C. P. (2014). An international consensus for assessing internet gaming disorder using the new DSM-5 approach. Addiction, 109(9), 1399-1406.

Pontes, H. M., \& Griffiths, M. D. (2015). Measuring DSM-5 internet gaming disorder: Development and validation of a short psychometric scale. Computers in Human Behavior, 45, 137-143.

Pontes, H. M., Király, O., Demetrovics, Z., \& Griffiths, M. D. (2014). The conceptualisation and measurement of DSM-5 internet gaming disorder: The development of the IGD-20 test. PLoS ONE, 9(10), 1-9.

Prensky, M. (2006). Don't bother me mom--i'm learning!: How computer and video games are preparing your kids for 21st century success - and how you can help! St Paul, MN: Paragon House.

Prot, S., Anderson, C., Gentile, D. A., Brown, S. C., \& Swing, E. L. (2014). The positive and negative effects of video game play. In A. Jordan \& D. Romer (Eds.), Media \& the wellbeing of children \& adolescents (pp. 109-128). New York, NY: Oxford University Press. 
Ramos, E. M., James, C. A., \& Bear-Lehman, J. (2005). Children's computer usage: Are they at risk of developing repetitive strain injury? Work, 25(2), 143-154.

Rosen, L. D., Cheever, N. A., \& Carrier, L. M. (Eds.). (2015). The wiley handbook of psychology, technology and society. United Kingdom: Wiley Blackwell.

Rosser, J. C. J., Lynch, P. J., Cuddihy, L., Gentile, D. A., Klonsky, J., \& Merrell, R. (2007). The impact of video games on training surgeons in the 21st Century. Archives of Surgery, 142(2), 181-186.

Rössler, P. (Ed.) (2017). The international encyclopedia of media effects (Vol. 1-4). United Kingdom: John Wiley \& Sons.

Ruggill, J. E., McAllister, K. S., Nichols, R., \& Kaufamn, R. (2017). Inside the video game industry: Game developers talk about the business of play. New York: Routledge.

Sepehr, S., \& Head, M. (2013, August 15-17). Online video game addiction: A review and an information systems research agenda. Paper presented at the The 19th Americas Conference on Information Systems, Chicago, Illinois.

Shaffer, H. J., LaPlante, D. A., LaBrie, R. A., Kidman, R. C., Donato, A. N., \& Stanton, M. V. (2004). Toward a syndrome model of addiction: multiple expressions, common etiology. Harvard Review of Psychiatry, 12(6), 367-374.

Silton, N. R. (2014). Innovative technologies to benefit children on the autism spectrum. United States: Medical Information Science Reference.

Simmons, L. L. (2008). The everything health guide to addiction and recovery: Control your behavior and build a better life. United States: The Everything Series.

Singapore Cybersports and Online Gaming Association. (2017). Community outreach. Retrieved from http://scoga.org/

Smith, R. D. (1997). CRS computer-related syndrome: The prevention and treatment of computer-related injuries. United States: Prometheus Books.

Starcevic, V., \& Aboujaoude, E. (2016). Internet addiction: Reappraisal of an increasingly inadequate concept. CNS Spectrums, 22(1), 7-13.

Stavropoulos, V., Beard, C., Griffiths, M. D., Buleigh, T., Gomez, R., \& Pontes, H. M. (2017). Measurement invariance of the internet gaming disorder scale - short-form (IGDS9-SF) between Australia, the USA and the UK. International Journal of Mental Health Addiction, 1-16.

Steinkuehler, C. A., \& Williams, D. (2006). Where everybody knows your (screen) name: Online games as 'third places". Journal of Computer-Mediated Communication, 11(4), 885-909.

Susi, T., Johannesson, M., \& Backlund, P. (2007). Serious games - an overview. Retrieved from http://www.diva-portal.org/smash/get/diva2:2416/FULLTEXT01.pdf

Sussman, S. (2017). Substance and behavioral addictions: Concepts, causes, and cures. United Kingdom: Cambridge University Press.

Tan, T. (2017, August 30). eSports and its athletes deserve more recognition. The Straits Times. Retrieved from http://www.straitstimes.com/tech/games-apps/esports-and-its-athletesdeserve-more-recognition.

Taylor, T. L. (2012). Raising the stakes: E-Sports and the professionalization of computer gaming. London, UK: MIT Press.

Van Rooij, A.J., Ferguson, C.J., Carras, M.C., Kardefelt-Winther, D., Shi, J., Aarseth, E., . . . Przybylski, A.K. (2018). A weak scientific basis for gaming disorder: Let us err on the side of caution. Journal of Behavioural Addictions, 7(1), 1-9. 
World Health Organisation (2018). Management of substance abuse: Gaming behaviour. Retrieved from: http://www.who.int/substance_abuse/activities/gaming_disorders/en/

Weis, R., \& Cerankosky, B. C. (2010). Effects of video-game ownership on young boys' academic and behavioral functioning. Psychological Science, 21(4), 463-470.

Weststar, J. (2015). Understanding video game developers as an occupational community. Information, Communication \& Society, 18(10), 1238-1252.

Wolf, M. J. P. (Ed.) (2012). Encyclopedia of video games: The culture, technology and art of gaming (Vol. 1-2). California, United States: ABC-CLIO.

Young, K., Pistner, M., O'Mara, J., \& Buchanan, J. (1999). Cyber disorders: The mental health concern for the new millennium. CyberPsychology \& Behaviour, 2(5), 475-479. 